\title{
Toxic chromium release from nickel mining sediments in surface waters, New Caledonia
}

\author{
Peggy Gunkel-Grillon • Christine Laporte-Magoni • \\ Monika Lemestre $\cdot$ Nicolas Bazire
}

Received: 14 May 2014 / Accepted: 4 July 2014

(C) Springer International Publishing Switzerland 2014

\begin{abstract}
Mining sediments are excavated from nickel ore exploitation in New Caledonia. In those sediments, chromium (Cr) occurs as $\mathrm{Cr}(\mathrm{III})$, but $\mathrm{Cr}(\mathrm{III})$ can be oxidized to the toxic $\mathrm{Cr}(\mathrm{VI})$ under oxic conditions, for instance in overlying water. Here, we aimed to determine whether mining sediments could release available $\mathrm{Cr}(\mathrm{VI})$ in surface waters. Water samples were collected in a mine and in the village downstream, and then were analysed for $\mathrm{Cr}$. Batch leaching experiments were performed on mining sediments in order to determine their exchangeable and their water-soluble $\mathrm{Cr}$ content as a function of $\mathrm{pH}$. Results show that mine waters contain high concentrations of total dissolved $\mathrm{Cr}$, of up to $0.73 \mathrm{mg} / \mathrm{L}$. Moreover, $\mathrm{Cr}(\mathrm{VI})$ concentration in village waters increases with the rainfall rate upto $0.34 \mathrm{mg} / \mathrm{L}$. Cr is released from sediments solely as $\mathrm{Cr}(\mathrm{VI})$. Desorption of chromate complexes is the main process involved in $\mathrm{Cr}$ release. We conclude that drainage of sediments mobilized by opencast $\mathrm{Ni}$ mines is a source of toxic $\mathrm{Cr}(\mathrm{VI})$ for surface waters.
\end{abstract}

Keywords Ni mines - Mining sediments - Chromium . Surface water - Ophiolitic substrate

\section{Introduction}

New Caledonia is a south-west pacific territory composed by one main island, in a middle of a large lagoon, and three smaller islands, "Loyalty Islands". The surrounding barrier

P. Gunkel-Grillon $(\bowtie) \cdot$ C. Laporte-Magoni · M. Lemestre .

N. Bazire

PPME Laboratory, Université de la Nouvelle-Calédonie BPR4, 98851 Nouméa cedex, Nouvelle-Calédonie, France

e-mail: peggy.gunkel-grillon@univ-nc.nc reef was listed by UNESCO on the World Heritage List under the name "The Lagoons of New Caledonia: Reef Diversity and Associated Ecosystems" on 7 July 2008. Another important characteristic of New Caledonia is that ophiolitic complexes cover $2 / 3$ of the main island, including alterites with $\mathrm{Ni}$ concentrations of economic interest. This Ni enrichment (laterite and saprolite) results from tropical miocene to present weathering of peridotites and pyroxenites. Since nickel ore is located at $10-30 \mathrm{~m}$ depth under lateritic levels, extraction technique adopted is strip mining, resulting in large opencast areas. After rainfalls, mining sediments are therefore conveyed along mining catchments, which are a significant water resource for domestic and agricultural use. Moreover, suspended particulate matter can reach quickly rivers and mouths of rivers because $\mathrm{Ni}$ mines are located close to the coast. It may result in a diffusive pollution of the lagoon. It is then crucial to understand the reactivity of the suspended particulate matter generated by mining activities. Among the elements present in mining sediments, the trivalent $\mathrm{Cr}$ form $(\mathrm{Cr}(\mathrm{III}))$ widely occurs in chromite $\left[(\mathrm{Mg}, \mathrm{Fe})(\mathrm{Al}, \mathrm{Cr}, \mathrm{Fe})_{2-}\right.$ $\mathrm{O}_{4}$ ]. $\mathrm{Cr}$ (III) leaching rate from chromite minerals depends on $\mathrm{pH}$, but the process is negligible since hexavalent chromium $(\mathrm{Cr}(\mathrm{VI}))$ is much more soluble than $\mathrm{Cr}(\mathrm{III})$ (Saputro et al. 2014). Cr(VI) is generated due to natural oxidation of $\mathrm{Cr}(\mathrm{III})$-bearing minerals. The occurrence of hexavalent chromium $(\mathrm{Cr}(\mathrm{VI}))$ in laterite is related to the oxidative reaction of $\mathrm{Cr}(\mathrm{III})$ with $\mathrm{Mn}$ oxides (Fandeur et al. 2009). In mining sediments, the predominant mineral phase is goethite $\mathrm{FeO}(\mathrm{OH})$. Pure goethite is known to adsorb $\mathrm{Cr}(\mathrm{VI})$, and the reaction is reversible (Deng et al. 1996). But besides readsorption of $\mathrm{Cr}(\mathrm{VI})$ onto $\mathrm{Fe}$ oxyhydroxides, several reactions with or without the support of dissolved species may occur at the interface of these natural mineral mixtures. Reactions may be $\mathrm{Cr}(\mathrm{VI})$ reduction and 
precipitation or $\mathrm{Cr}(\mathrm{VI})$ reduction and readsorption (Saputro et al. 2014). Mining sediments may then become a source of chromium for aqueous media by $\mathrm{Cr}(\mathrm{VI})$ or $\mathrm{Cr}(\mathrm{III})$ desorption, or dissolution of $\mathrm{Cr}$ (III) precipitates formed at the interface. In opencast $\mathrm{Ni}$ mining systems, generated sediments contain $\mathrm{Cr}$ (III)-bearing phases, Mn oxides and Fe oxyhydroxides, suggesting that after excavation, they should become a reservoir of $\mathrm{Cr}(\mathrm{III})$ and $\mathrm{Cr}(\mathrm{VI})$; since under oxic conditions, the transformation of $\mathrm{Cr}$ (III) to $\mathrm{Cr}(\mathrm{VI})$ should be facilitated and the secondary sorption reaction onto $\mathrm{Fe}$ oxides should significantly occur. The aim of the present study was to determine under realistic environmental conditions which oxidative state $\mathrm{Cr}(\mathrm{III})$ or $\mathrm{Cr}(\mathrm{VI})$ is significantly leached from $\mathrm{Cr}(\mathrm{III})$-bearing minerals and then which oxidative state is involved in chromium circulation in surface waters influenced by Ni mining activities. $\mathrm{Cr}(\mathrm{VI})$ is considered as the most toxic form for living organisms. It can affect vital organs of freshwater fish (Mishra and Mohanty 2008), cause toxic and tissuespecific genotoxic effects to freshwater stinging catfish (Ahmed et al. 2013), and affect testicular function of adult male rats (Marouani et al. 2012) or photosynthesis in plants (Rodriguez et al. 2012). It is also carcinogenic for the human body (International Agency for Research on Cancer 1990). $\mathrm{Cr}(\mathrm{III})$ is an essential nutrient for animal metabolism (Anderson 1981), but accumulated at high levels, it can anyway generate serious troubles and diseases (Meibian et al. 2008).

The objectives of the present study were to analyse chromium content in mining-influenced surface waters and to evaluate the potential of $\mathrm{Cr}$ release from mining sediments. The exchangeable $\mathrm{Cr}(\mathrm{VI})$ content was determined with $\mathrm{NH}_{4} \mathrm{H}_{2} \mathrm{PO}_{4}$ or $\mathrm{KH}_{2} \mathrm{PO}_{4} 0.1 \mathrm{M}$ solution designed to remove sorbed chromate. The water-soluble $\mathrm{Cr}$ content as a function of $\mathrm{pH}$ is also determined. $\mathrm{pH}$ is one of the key parameters for heavy metals mobility in sediments (Gäbler 1997), and thus, the water-soluble $\mathrm{Cr}$ content is determined for a wide range of $\mathrm{pH}$ encountered in natural waters. This is the first time that $\mathrm{Cr}$ concentration and speciation are determined in waters influenced by $\mathrm{Ni}$ mining activities in New Caledonia and the results of the present study may then have implications for management of mining catchments.

\section{Experimental}

Site description

New Caledonia is located in the south-west Pacific Ocean $\left(20-23^{\circ} \mathrm{S}\right)$. Its subtropical climate varies from a hot and humid period with high rainfalls (November to March) to a dry period (June to August). The studied site is the mining centre of Poro, the oldest mining centre (exploitation from 1874), located on the east coast of New Caledonia. The mining site includes ultramafics (harzburgite, websterite) and their derived weathered rocks (saprolite, laterite). The Poro catchment surface is 33.3 ha, and the annual rainfall average is 2,801.5 mm/year (average of 2013, 2012, 2011 and 2010 for Poindimié; www.meteo.nc). Infrastructures exist to ensure the waters retention using bridging methods of the bench walls to sustain the residues and attenuate the erosive capacity of the waters' flow and also using rainwater channelling, drainage and sedimentation.

\section{Sampling}

Five sampling sites were selected from the top of the mining catchment to the mouth of the river (Fig. 1). A, B and $\mathrm{D}$ are sites located within the mine boundaries, while $\mathrm{E}$ and $\mathrm{F}$ are located downstream in the village of Poro.

Water samples were collected at the top of the mine at a resurgence just below carries (A), at the bottom of the mine outlet the latest settling tank of the mine (D), in the river going through Poro village (E) and at the mouth of the river (F). Samples were collected within the humid period from 14 March 2011 to 29 April 2011 after two high rainfall rates $(100 \mathrm{~mm} / 24 \mathrm{~h}$ and $132.5 \mathrm{~mm} / 24 \mathrm{~h})$, a medium and a low rainfall rate $(50 \mathrm{~mm} / 24 \mathrm{~h}$ and $3.5 \mathrm{~mm} / 24 \mathrm{~h})$ and without rainfall $(0 \mathrm{~mm} / 24 \mathrm{~h})$. Water samples, collected in HDPE bottles, were kept at $6{ }^{\circ} \mathrm{C}$ prior to analysis.

Two sediment samples were collected: one at the top of the mine in a settling tank located at the upstream part of the first outlet (B) and another one at the bottom of the mine in the latest settling tank of the mine (D). About $2 \mathrm{~kg}$ was collected from the top layer $(0-30 \mathrm{~cm})$, dried at $45^{\circ} \mathrm{C}$ until constant weight, sieved at $2 \mathrm{~mm}$ and manually mixed to obtain a homogenous material.

\section{Extraction procedures and analytical techniques}

Exchangeable anionic chromium (exchangeable $\mathrm{Cr}(\mathrm{VI})$ ) was extracted by shaking $1 \mathrm{~g}$ of sediment with $34 \mathrm{~mL}$ of $\mathrm{KH}_{2} \mathrm{PO}_{4} 0.1 \mathrm{M}\left(1 \mathrm{~h}, 20^{\circ} \mathrm{C}\right)$.

Water-soluble $\mathrm{Cr}$ was extracted as a function of $\mathrm{pH}$ by shaking $6 \mathrm{~g}$ of sediments in $30 \mathrm{ml}$ of deionized water with $\mathrm{pH}$ acidified or alkalinized with $\mathrm{HNO}_{3}$ or $\mathrm{NaOH}$ or buffered with MES (2-(N-morpholino)ethanesulfonic acid) or HEPES (4-(2-hydroxyethyl)-1-piperazineethanesulfonic acid) or MOPS (3-(N-morpholino)propanesulfonic acid) $0.1 \mathrm{M}$ around neutral $\mathrm{pH}$ because of the buffer capacity of sediments.

Water samples and leachates were filtered at $0.22 \mu \mathrm{m}$ before analysis. $\mathrm{Cr}(\mathrm{VI})$ concentration was measured using spectrocolorimetric determination of a complex formed with diphenylcarbazide (absorption at $540 \mathrm{~nm}$ ), and total 
Fig. 1 The mining centre, the village of Poro and location of the five sampling sites at the top of the mining catchment $(A, B)$, at the bottom of the mine $(D)$, in the river $(E)$ and at its mouth $(F)$. Pictures of the river before and after a rainfall show particulate matter run-off

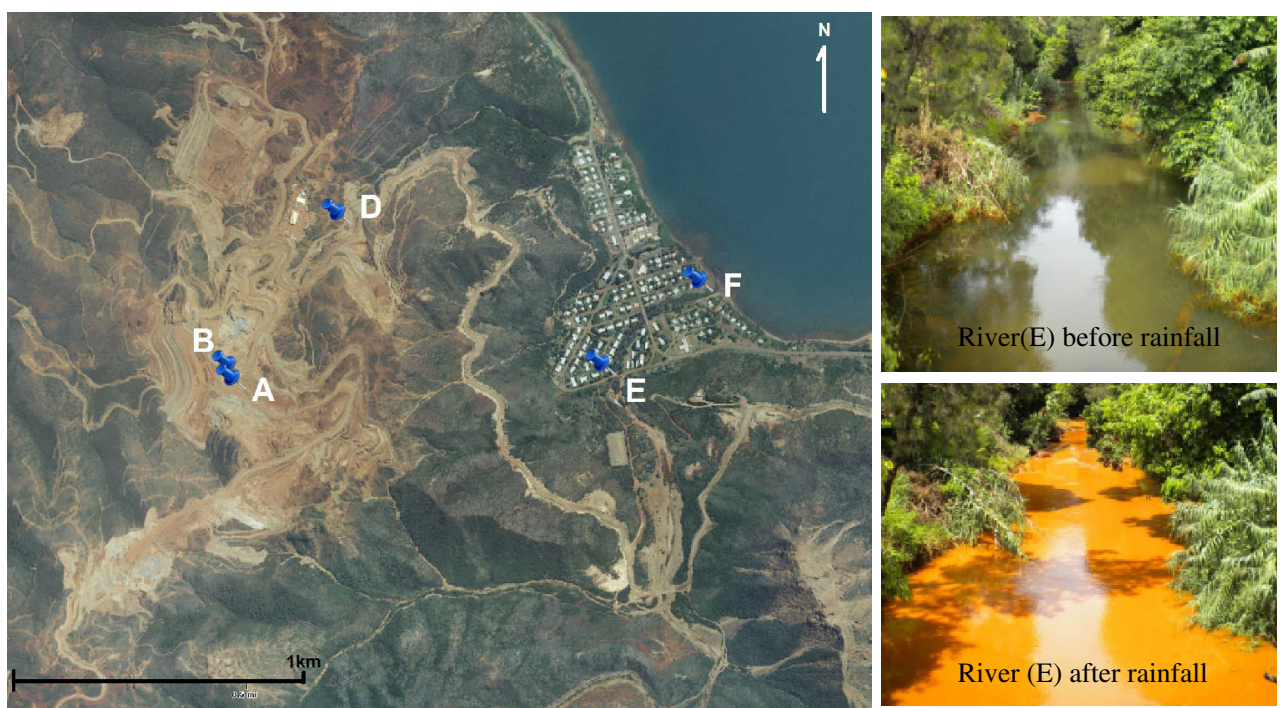

$\mathrm{Cr}(\mathrm{Cr}(\mathrm{III})+\mathrm{Cr}(\mathrm{VI}))$ was measured by atomic absorption spectrometry according to the AFNOR French procedure (NF EN 1233, AFNOR 1996). All reagents were of analytical grade.

Particle size analysis (volume-based measurement) was performed using a Malvern Mastersizer 2000 Particle Size Analyser. Mineral phases were identified from powder by X-ray diffraction of sediments with Inel CPS 120 instrument.

\section{Results}

Dissolved chromium content in surface waters

Total dissolved $\mathrm{Cr}$ content in surface waters is high and ranges from 0.05 to $2.41 \mathrm{mg} / \mathrm{L}$ (Fig. 2a). Cr contents are higher in mine waters than in village waters. At the top of the mine (A), total $\mathrm{Cr}$ decreases as the rainfall rate increases, while in the village, at the mouth of the river (F) it increases as the rainfall rate increases.

Dissolved $\mathrm{Cr}(\mathrm{VI})$ content in mine waters $(\mathrm{A}, \mathrm{D})$ is very high ranging from 0.18 to $1.62 \mathrm{mg} / \mathrm{L}$ (Fig. 2 b). The dissolved $\mathrm{Cr}(\mathrm{VI})$ content in village waters $(\mathrm{E}, \mathrm{F})$ is lower than in mine water ranging from 0.02 to $0.34 \mathrm{mg} / \mathrm{L}$ (Fig. 2c). $\mathrm{Cr}(\mathrm{VI})$ content at the top of the mine (A) decreases as the rainfall rate increases (Fig. 2 b) such as previously observed for the total $\mathrm{Cr}$ content. $\mathrm{Cr}(\mathrm{VI})$ content reduces significantly with rainfall rate at the top of the mine (A) due to dilution even if the concentrations remain very high. At the bottom of the mine (D), it is quite constant (Fig. 2c). In village waters (E, F), $\mathrm{Cr}(\mathrm{VI})$ content increases significantly with the rainfall rate (Fig. 2c). After rainfalls, there is a sediment load in the river (Fig. 1) and $\mathrm{Cr}(\mathrm{VI})$ dilution is then probably counterbalanced by $\mathrm{Cr}$ remobilization from suspended materials provided by mining sediments. As demonstrated for $\mathrm{Pb}$ and $\mathrm{Zn}$ (Superville et al. 2014), metal desorption from disturbed sediments is the most relevant process responsible for the $\mathrm{Cr}$ content increase in surface waters.

Chromium leaching behaviour in mining sediments

In mining sediments, chromium is one of the major components after iron and magnesium since chromium oxide content is, respectively, 1.6 and $3.1 \%$ in sediments collected at the top (B) and the bottom (D) of the mine (Table 1). The main mineral phases identified for both sediments on the X-ray diffractograms are goethite, talc and serpentine; goethite is dominant.

\section{Exchangeable hexavalent chromium as a function of particle size}

Exchangeable $\mathrm{Cr}(\mathrm{VI})$ content is very high for sediments collected at the top of the mine (B) with $577 \mathrm{mg} / \mathrm{kg}$, while it is 9 times lower for those collected at the bottom (D) with $64 \mathrm{mg} / \mathrm{kg}$ (Table 1). These concentrations are in good agreement with contents of exchangeable $\mathrm{Cr}(\mathrm{VI})$ found for ultramafic soils with contents sometimes upper than $1000 \mathrm{mg} / \mathrm{kg}$ (Becquer et al. 2003, Garnier et al. 2006, Raous et al. 2013). With the hypothesis of desorption reaction, anionic hexavalent chromium content should be related to sediments texture. Sediment B is fractionated in three granulometric fractions by sieving in order to get five samples with different texture: crude sediment B with Dv90 $=76 \mu \mathrm{m}$, crude sediment D with Dv90 $=502 \mu \mathrm{m}$, the granulometric fraction of $\mathrm{B}>2000 \mu \mathrm{m}$ (no size analysis possible for such large particles) and two granulometric fractions of B with Dv90 $=44$ and Dv90 $=154 \mu \mathrm{m}$. 


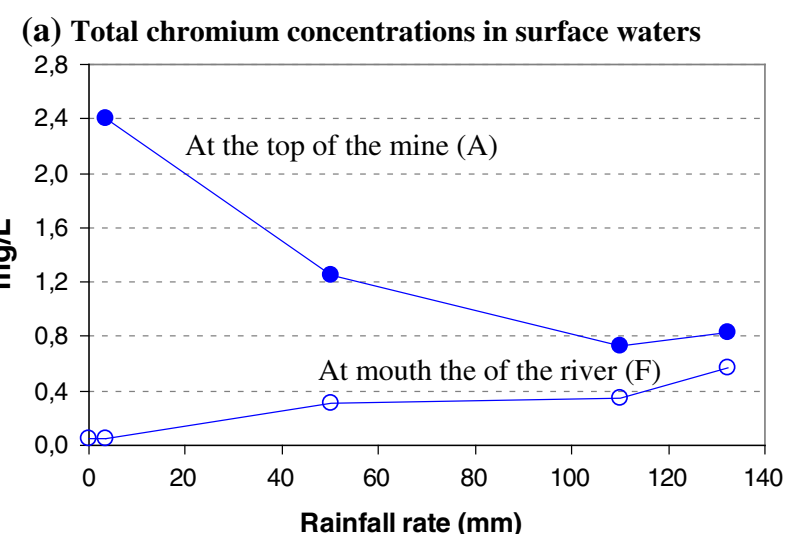

(b) Hexavalent chromium concentrations in mine waters

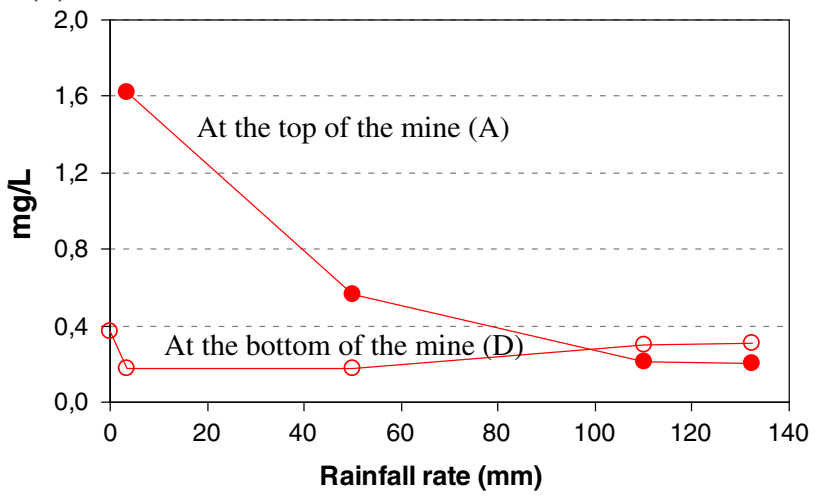

(c) Hexavalent chromium concentrations in village waters

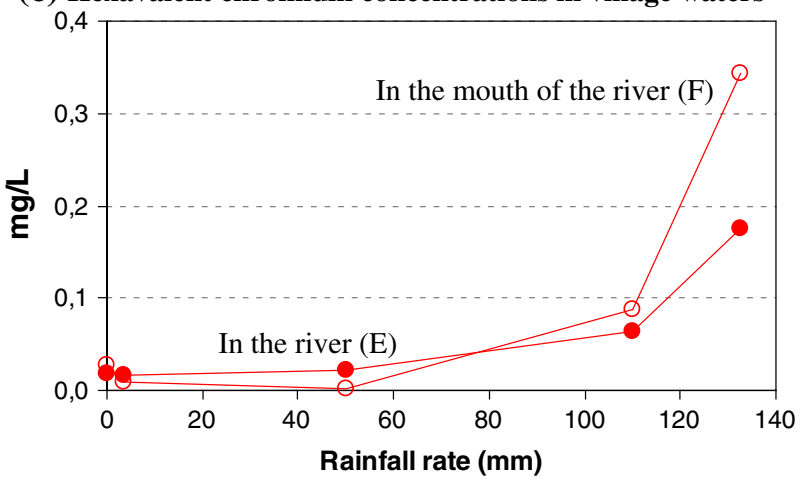

Fig. 2 Total chromium and hexavalent chromium concentrations as a function of the rainfall rate. They both decrease at the top of the mine, while they both increase at the mouth of the river

Results show that exchangeable $\mathrm{Cr}(\mathrm{VI})$ content decreases when particle size increases (Fig. 3a). Cr(VI) occurs then as sorption complexes. Mining sediments are then an important reservoir of exchangeable $\mathrm{Cr}(\mathrm{VI})$, especially the thinnest fractions.

\section{Water-soluble chromium as a function of time and $\mathrm{pH}$}

Batch leaching experiments on the crude sediment $\mathrm{B}$ (fraction Dv90 $=76 \mu \mathrm{m}$ ) were performed at various $\mathrm{pH}$ and demonstrate that no significant amount of water-
Table 1 Physico-chemical properties of mining sediments: mean values $(n=3)$ for elemental composition (percentage weight), for exchangeable anionic chromium content and for Dv 90 (maximum particle diameter below which $90 \%$ of the sample volume exists)

\begin{tabular}{|c|c|c|}
\hline \multirow[t]{2}{*}{ (wt\%) } & \multicolumn{2}{|c|}{$\begin{array}{l}\text { Physico-chemical properties of mining sediments } \\
\text { collected }\end{array}$} \\
\hline & $\begin{array}{l}\text { At the top of the mine } \\
\text { (B) }\end{array}$ & $\begin{array}{l}\text { At the bottom of the } \\
\text { mine (D) }\end{array}$ \\
\hline $\mathrm{Fe}_{2} \mathrm{O}_{3}$ & 44.5 & 44.6 \\
\hline $\mathrm{SiO}_{2}$ & 20.3 & 23.2 \\
\hline $\mathrm{MgO}$ & 11.8 & 11.0 \\
\hline $\mathrm{Cr}_{2} \mathrm{O}_{3}$ & 1.6 & 3.1 \\
\hline $\mathrm{NiO}$ & 2.4 & 1.5 \\
\hline $\mathrm{Al}_{2} \mathrm{O}_{3}$ & 1.6 & 2.0 \\
\hline $\mathrm{MnO}$ & 0.7 & 0.6 \\
\hline $\mathrm{CaO}$ & 0.05 & 0.05 \\
\hline $\mathrm{TiO}_{2}$ & 0.05 & 0.10 \\
\hline $\mathrm{CoO}$ & 0.09 & 0.07 \\
\hline $\begin{array}{l}\text { Exch. } \mathrm{Cr}(\mathrm{VI}) \\
(\mathrm{mg} / \mathrm{kg})\end{array}$ & $577 \pm 9$ & $64 \pm 5$ \\
\hline Dv $90(\mu \mathrm{m})$ & $76 \pm 5$ & $502 \pm 11$ \\
\hline
\end{tabular}

soluble $\mathrm{Cr}(\mathrm{III})$ is detected (Fig. 3b). It indicates that $\mathrm{Cr}$ is only released as $\mathrm{Cr}(\mathrm{VI})$ and that no significant $\mathrm{Cr}(\mathrm{III})$ desorption or dissolution of $\mathrm{Cr}(\mathrm{III})$ precipitates occurs. $\mathrm{Cr}(\mathrm{VI})$ release is fast (high concentrations measured as soon as $1 \mathrm{~h}$ ), and the rate of dissolved $\mathrm{Cr}$ reaches a maximum value of $358 \pm 16 \mathrm{mg} / \mathrm{kg}$ after $8 \mathrm{~h}$ for $\mathrm{pH} 12.6$ and $31 \pm 1 \mathrm{mg} / \mathrm{kg}$ for $\mathrm{pH} 7.5$ (Fig. 3b). Over the entire $\mathrm{pH}$ range tested (5.9-12.6), the water-soluble $\mathrm{Cr}(\mathrm{VI})$ fraction increases with the $\mathrm{pH}$ of the solution (Fig. 3c) and no significant amount of $\mathrm{Cr}(\mathrm{III})$ was measured. It is known that chromate ions adsorption by $\mathrm{Mn}, \mathrm{Fe}$ and $\mathrm{Al}$ oxides decreases as $\mathrm{pH}$ increases (Richard and Bourg 1991). The process involved with mining sediments, which main mineral phase is goethite, is then the opposite process, i.e. increasing $\mathrm{Cr}(\mathrm{VI})$ desorption with $\mathrm{pH}$. Here, we then demonstrate that mining sediments are a reservoir of easily leachable $\mathrm{Cr}(\mathrm{VI})$, especially when alkaline media are of concern. Afterwards, dissolved $\mathrm{Cr}(\mathrm{VI})$ can be reduced to $\mathrm{Cr}(\mathrm{III})$ in the aqueous media by organic matter such as humic substances (Saputro et al. 2014).

\section{Conclusion}

Mine waters and village waters contain high $\mathrm{Cr}$ contents as $\mathrm{Cr}(\mathrm{VI})$ but also as $\mathrm{Cr}(\mathrm{III})$. Batch experiments demonstrated that mining sediments are an important reservoir of easily leachable $\mathrm{Cr}(\mathrm{VI})$, and $\mathrm{Cr}(\mathrm{VI})$ leaching depends on $\mathrm{pH}$ and on sediments texture. $\mathrm{Cr}$ (III) leaching is negligible, and no significant $\mathrm{Cr}(\mathrm{III})$ desorption or $\mathrm{Cr}(\mathrm{III})$ precipitates 
(a) Exchangeable hexavalent chromium content as a function of particle size

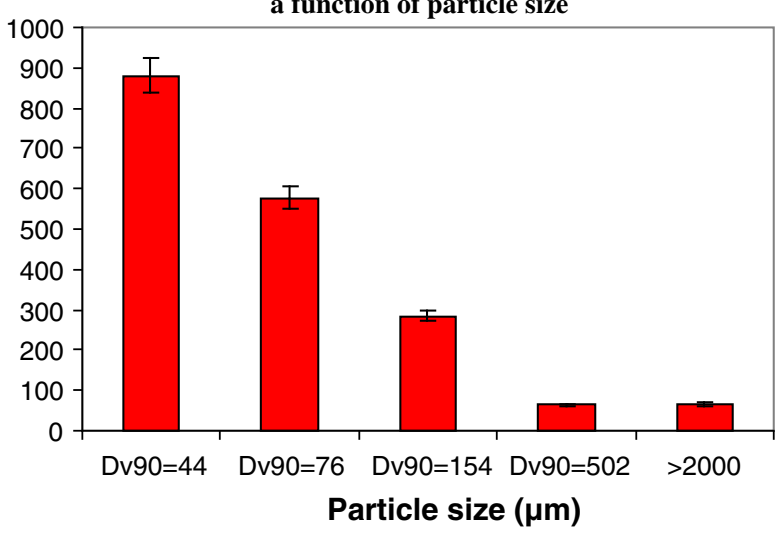

(b) Water soluble chromium content

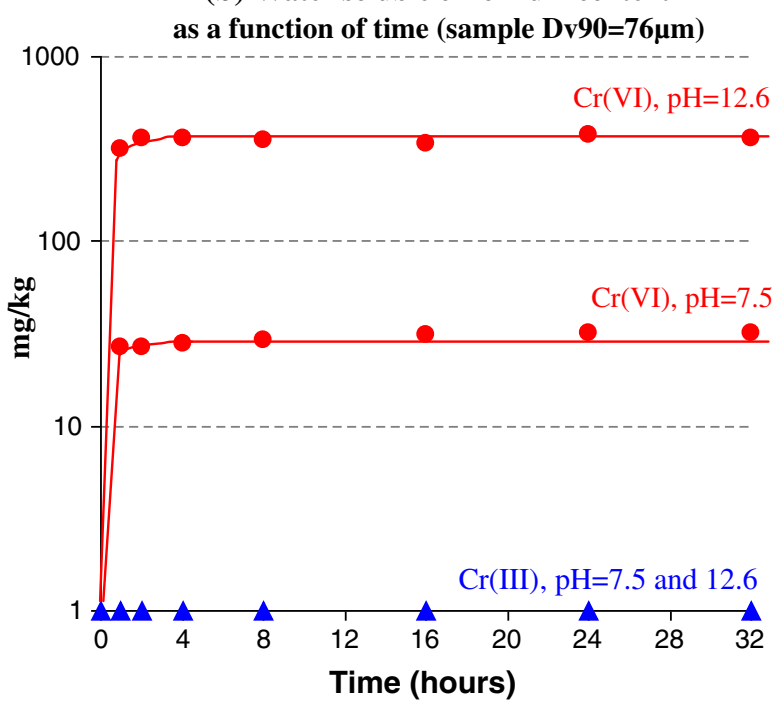

(c) Water soluble chromium content

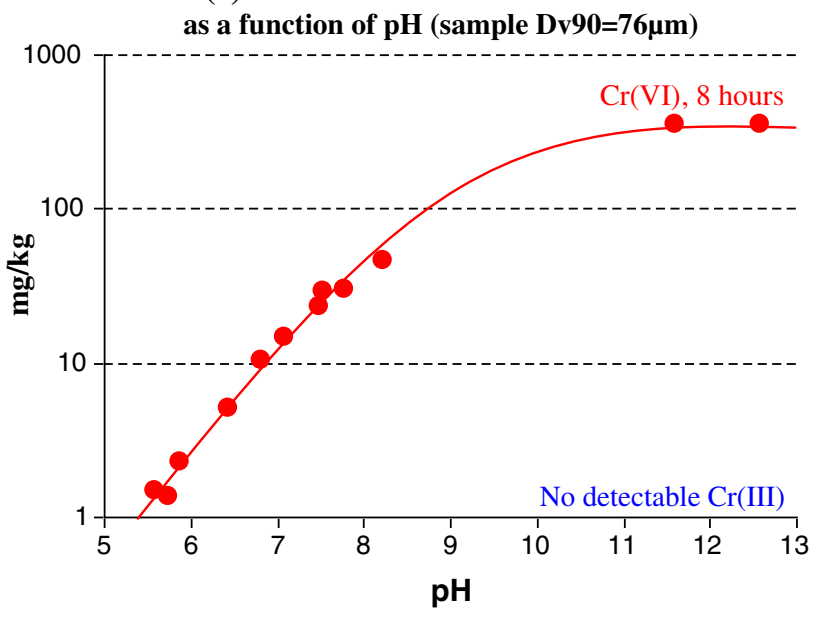

Fig. 3 Chromium leaching behaviour in mining sediments. Mining sediments release chromium only as its hexavalent form

dissolution occurs. Cr circulation in water is then here related to $\mathrm{Cr}(\mathrm{VI})$ desorption. Thus, run-off from the mines carries along suspended particulate matters able to easily and quickly release $\mathrm{Cr}(\mathrm{VI})$ when the medium is disturbed and/or when the $\mathrm{pH}$ of the media increases such as in the mouth of the river or in the sea water. Afterwards, $\mathrm{Cr}(\mathrm{VI})$ can be reduced to $\mathrm{Cr}(\mathrm{III})$ in the aqueous media depending on local chemical composition. This study demonstrates, through the example of Poro, that drainage of ultramafic material mobilized from $\mathrm{Ni}$ mines is a source of $\mathrm{Cr}$ as $\mathrm{Cr}(\mathrm{VI})$ for local surface waters. For a sustainable exploitation of mining resource compatible with the conservation of the natural environment of New Caledonia, the authors greatly encourage mining industries to prevent transport of solid matter in mining catchment including the thinnest solid matter.

Acknowledgments This work was supported by the National Centre for Technological Research on "Nickel and its Environment" (Centre National de Recherche Technologique, CNRT "Nickel et son environnement") within the programme "functioning of small mining catchment areas" (2009-2014).

\section{References}

AFNOR (1996) NF EN 1233, Water quality-determination of chromium- Atomic absorption spectrometric methods

Ahmed MK, Kundu GK, Al-Mamun MH, Sarkar SK, Akter MS, Khan MS (2013) Chromium (VI) induced acute toxicity and genotoxicity in freshwater stinging catfish, Heteropneustes fossilis. Ecotoxicol Environ Saf 92:64-70

Anderson RA (1981) Nutritional role of chromium. Sci Total Environ 17:13-29

Becquer T, Quantin C, Sicot M, Boudot JP (2003) Chromium availability in ultramafic soils from New Caledonia. Sci Total Environ 301:251-261

Deng Y, Stjernström M, Banwart S (1996) Accumulation and remobilization of aqueous chromium (VI) at iron oxides surfaces: application of a thin-film continuous flow-trough reactor. J Contam Hydrol 21:141-151

Fandeur D, Juillot F, Morin G, Olivi L, Cognigni A, Webb SM, Ambrosi JP, Fristch E, Guyot F, Gordon E, Brown JR (2009) XANES Evidence for Oxidation of $\mathrm{Cr}(\mathrm{III})$ to $\mathrm{Cr}(\mathrm{VI})$ by $\mathrm{Mn}$ Oxides in a Lateritic Regolith developed on Serpentinized Ultramafic Rocks of New Caledonia. Environ Sci Technol 43:7384-7390

Gäbler H-E (1997) Mobility of heavy metals as a function of $\mathrm{pH}$ of samples from an overbank sediment profile contaminated by mining activities. J Geochem Explor 58:185-194

Garnier J, Quantin C, Martins ES, Becquer T (2006) Solid speciation and availability of chromium in ultramafic soils from Niquelândia, Brazil. J Geochem Explor 88:206-209

International Agency for Research on Cancer (1990) World Health Organization, Chromium, Nickel and Welding. IARC Monographs on the Evaluation of Carcinogenic Risks to Humans, Volume 49, IARRC, WHO, Lyon, 1990

Marouani N, Tebourbi O, Mahjoub S, Yacoubi MT, Sakly M, Benkhalifa M, Rhouma KB (2012) Effects of hexavalent chromium on reproductive functions of male adult rats. Reprod Biol 12(2):119-133

Meibian Z, Zhijian C, Qing C, Hua Z, Jianlin L, Jiliang H (2008) Investigating DNA damage in tannery workers occupationally exposed to trivalent chromium using comet assay. Mut Res $654: 45-51$ 
Mishra AK, Mohanty B (2008) Acute toxicity impacts of hexavalent chromium on behaviour and histopathology of gill, kidney and liver of the freshwater fish Channa punctatus (Bloch). Environ Toxicol Pharmacol 26:136-141

Raous S, Echevarria G, Sterckeman T, Hanna K, Thomas F, Martins ES, Becquer T (2013) Potentially toxic metals in ultramafic mining materials: identification of the main bearing and reactive phases. Geoderma 192:111-119

Richard FC, Bourg ACM (1991) Aqueous geochemistry of chromium: a review. Water Res 25(7):807-816

Rodriguez E, Santos C, Azevedo R, Moutinho-Pereira J, Correia C, Dias MC (2012) Chromium (VI) induces toxicity at different photosynthetic levels in pea. Plant Physiol Biochem 53:94-100
Saputro S, Yoshimura K, Matsuoka S, Takehara K, Narsito, Aizawa J, Tennichi Y (2014) Speciation of dissolved chromium and the mechanisms controlling its concentration in natural water. Chem Geol 364:33-44

Superville P-J, Prygiel E, Magnier A, Lesven L, Gao Y, Bæyens W, Ouddane B, Dumoulin D, Billon G (2014) Daily variations of Zn and $\mathrm{Pb}$ concentrations in the Deûle River in relation to the resuspension of heavily polluted sediments. Sci Total Environ 470-471:600-607 